\title{
Persistent idiopathic facial pain, a diagnosis and treatment of challenge. Case report
}

\author{
Dor facial idiopática persistente, diagnóstico e tratamento desafiadores. Relato de caso
}

Raphael de Souza Borges ${ }^{1}$, Durval Campos Kraychete ${ }^{2}$, Emilly Leticia Gusmão Borges ${ }^{3}$, Valmir Machado de Melo Filho

DOI 10.5935/2595-0118.20180053

\section{ABSTRACT}

BACKGROUND AND OBJECTIVES: Persistent idiopathic facial pain is a chronic disease with neuropathic origin, whose etiology is usually unknown; it is a medical condition that does not respond satisfactorily to drug therapy. It is also a disease with a major impact on patient quality of life and difficult to diagnose. This study aimed to report the diagnosis of a complex, persistent idiopathic facial pain, the pharmacological intervention taken and the adoption of integrative and complementary practices for the management of persistent idiopathic facial, as well as the clinical course and the impact of these actions on the patient's quality of life.

CASE REPORT: A female patient, 52, diagnosed 06 years ago as a carrier of persistente idiopathic facial pain associated with bruxism and temporomandibular disorders. The patient presented with a complaint of orofacial pain which did not meet the diagnostic criteria for temporomandibular disorders. The patient also presented myofascial and trigeminal neuralgia pain in the left buccal region which emerged after performing a root canal procedure. The therapeutic plan adopted was based on pharmacological therapy with pregabalin $(450 \mathrm{mg})$ in combination with venlafaxine hydrochloride $(150 \mathrm{mg})$, continuously. As additional measures, weekly acupuncture sessions, therapy sessions with psychologists, including hypnosis and meditation, as well as peripheral nerve and a venous block during crises and botulinum toxin application were applied. CONCLUSION: The therapeutic plan adopted led to a considerable improvement in the patient's quality of life, evidenced by the reduction in pain intensity and a decrease in the frequency of painful crises. The need for interdisciplinary monitoring, as it is a multifactorial disease, as well as for the ongoing training of various categories of health professionals involved in the treatment of persistent idiopathic facial, given that it is a complication which is rare and difficult to diagnose, is observed.

Keywords: Atypical facial pain, Chronic pain, Facial pain, Pain, Quality of life.

\footnotetext{
1. Universidade Federal da Bahia, Faculdade de Medicina, Salvador, BA, Brasil.

2. Universidade Federal da Bahia, Departamento de Anestesiologia, Salvador, BA, Brasil.

3. Universidade Federal da Bahia, Faculdade de Odontologia, Salvador, BA, Brasil.

Submitted in March 18, 2018.

Accepted for publication on August 01, 2018

Conflict of interests: none - Sponsoring sources: none.

Correspondence to:

Durval Campos Kraychette

E-mail:dkt@terra.com.br

(C) Sociedade Brasileira para o Estudo da Dor
}

\section{RESUMO}

JUSTIFICATIVA E OBJETIVOS: A dor facial idiopática persistente é uma doença crônica de origem neuropática cuja etiologia é normalmente desconhecida. É uma condição médica que não responde satisfatoriamente à farmacoterapia. Também é uma doença com grande impacto na qualidade de vida do paciente, e difícil de diagnosticar. O objetivo deste estudo foi reportar o diagnóstico de dor facial idiopática persistente, complexa, a intervenção farmacológica usada e a adoçâo de práticas integrativas e complementares para o manuseio da dor facial idiopática persistente, além do curso clínico e o impacto dessas açôes na qualidade de vida do paciente.

RELATO DO CASO: Paciente do sexo feminino, 52 anos, diagnosticada há 6 anos como portadora de dor facial idiopática persistente associada a bruxismo e distúrbio temporomandibular. A paciente apresentou-se com queixa de dor orofacial que não atendeu os critérios diagnósticos de distúrbio temporomandibular. A paciente também apresentou dor miofascial e neuralgia do trigêmeo na regiáo esquerda da boca que surgiram depois de um procedimento de tratamento de canal. O plano terapêutico adotado foi pregabalina $(450 \mathrm{mg})$ em combinação com cloridrato de venlafaxina $(150 \mathrm{mg})$, contínuo. Como medidas adicionais, sessóes semanais de acupuntura, terapia com psicólogo, incluindo hipnose e meditação, além de bloqueio do nervo periférico e bloqueio venoso durante as crises e aplicação de toxina botulínica. CONCLUSÁO: O plano terapêutico adotado trouxe melhora considerável na qualidade de vida da paciente, evidenciada pela redução da intensidade da dor e pela diminuição na frequência das crises dolorosas. Há necessidade de monitoramento interdisciplinar, por ser uma doença multifatorial, e de capacitação constante nas diversas categorias de profissionais de saúde envolvidos no tratamento da dor facial idiopática persistente, vista ser uma complicaçáo rara e difícil de diagnosticar.

Descritores: Dor, Dor crônica, Dor facial, Dor facial atípica, Qualidade de vida.

\section{INTRODUCTION}

The face's functional and morphological characteristics, combined with the complexity of the pain phenomenon, predispose it to the existence of innumerable sources of pain. Persistent idiopathic facial pain (PIFP) comprises of a complex pain condition of neuropathic origin ${ }^{1,2}$ with its chronic nature highlighted by its still unknown etiology and its refractoriness to current treatments ${ }^{3}$. The anatomical and nervous complexity of the head; the 
similarities in signs and symptoms among the pain type affecting the face, associated with the absence of specific and/or sensitive instruments, makes it difficult to diagnose PIFP accurately $y^{4}$. PIFP is composed of persistent facial pain, usually burning, restricted to the hemiface, which doesn't meet the criteria for neuralgias, and is not associated with objective neurological signs or the presence of organic lesions in image exams and laboratory studies ${ }^{1,5}$.

The PIFP's prevalence in the general population is estimated at $0.03 \%$, its incidence is still unknown, although among patients undergoing endodontic treatment there is an incidence of $3-6 \%$. PIFP is not associated with sensory loss or other neurological deficits and is usually related to anxiety and depression, catastrophizing and poor quality of life ${ }^{7}$.

PIFP's pathophysiology is still unknown, which makes treatment difficult and often inefficient. There are few randomized controlled studies, and most treatment options are based on open studies. Tricyclic antidepressants such as amitriptyline (50$100 \mathrm{mg} /$ day) or nortriptyline $(20-50 \mathrm{mg})$ are effective if used for many months. Selective serotonin and noradrenaline inhibitors (duloxetine, venlafaxine and mirtazapine) are also used but are often ineffective. Patients benefit from simultaneous psychotherapy to improve their quality of life ${ }^{7}$.

Pain psychology, from a functional perspective, requires the understanding of pain as a behavioral event, which is the result of a unique interrelationship between biological and environmental conditions, in such a way that none of them can separately explain the phenomenon ${ }^{4}$. Thus, including a psychodiagnostic evaluation in the therapeutic plan is necessary; noteworthy as a potentially useful resource, it can be helpful for obtaining the elements necessary to plan and develop interventions ${ }^{8}$.

\section{CASE REPORT}

Female patient, 52 years old, married and a public servant. Five years ago, after having a tooth canal performed in the lower left $1^{\text {st }}$ premolar (34) and the lower left $1^{\text {st }}$ molar (36), she had pain in the left inferior hemiface region, characterized as diffuse, pulsatile and in shock, low frequency and intensity. The pain evolved with gradual intensification and irradiation to the upper left quadrant region, becoming more continuous and burning. After the pain was established, the patient sought a dental surgeon who discarded the relationship between the pain and the endodontic treatment. As symptoms persisted, the patient sought another dental surgeon who indicated laser therapy, and, after four sessions, her pain was intensified. She also sought a neurologist who requested some imaging tests (Skull and Face X-rays, Skull Magnetic Resonance), but no abnormality was found, and the diagnosis of trigeminal neuralgia (TN) was made. He initiated oral pharmacological treatment with daily doses of gabapentin $(900 \mathrm{mg})$ and paracetamol $(1000 \mathrm{mg})$, without improvement, even after increasing the dose of gabapentin $(3600 \mathrm{mg} /$ day).

Three years ago, after an intense pain crisis associated with stress, she again sought out a dental surgeon and retreated the root canal in the unit (34). With the persistence of the symptoms, she went to another dentist specialized in orofacial pain, from whom she received the diagnosis of bruxism associated with temporoman- dibular joint dysfunction (TMJD), and who referred the patient to a pain specialist who diagnosed PIFP. The patient started using pregabalin (450mg) in combination with venlafaxine $(150 \mathrm{mg})$ and a complementary treatment consisting of weekly acupuncture sessions and peripheral blockade. A local inferior alveolar branch block was performed four times during the seizures, but no response was detected. It was replaced by a venous block with the use of $2 \%$ lidocaine with an initial dosage of $250 \mathrm{mg}$ that evolved to $400 \mathrm{mg}$, with good therapeutic response. Subsequent to the venous blockade, local application of botulinum toxin 200IU was performed with no improvement in the condition.

The patient referred to the use of psychotherapy, some hypnosis and meditation sessions, as important contributors to her ability to deal with her clinical condition and its improvement. During the physical examination, it was found that sensitivity and motricity were preserved symmetrically in the left hemiface.

During pain crises, the patient reported pain intensity of 10 (continuous visual scale), pulsatile, burning, with the presence of allodynia and irradiation to the region innervated by the superior alveolar branch, with Douleur Neuropathique en 4 questions (DN-4) positive for neuropathic pain (6/10). In the periods between crises, the pain was diffuse in the lower left quadrant region and without allodynia. The pain worsened during stress and improvement was associated with rest and pleasurable activities, with DN-4 negative for neuropathic pain (3/10).

For the psychodiagnostic part of treatment 6 evaluations were applied: Personal and Professional Life History Interview; DSM-V open-ended interview for anxiety and depression; LIPP's Stress Symptom Inventory for adults (LSSI); Hospital Anxiety and Depression Scale (HADS); Quality of Life Scale (SF-36); Pittsburgh Sleep Quality Index (PSQI-BR).

The application of LIPP showed that the patient presented physical and psychological symptoms of anxiety, constantly thinking about her pain, as well as apathy and fatigue. According to the SF-36, she presented impairments in emotional and social aspects with a high level of pain when performing her daily activities that lead to a negative perception of her health. In addition, the patient had low sleep quality (analyzed using the PSQI-BR), which corroborated the increase in pain and stress levels and compromised her quality of life.

\section{DISCUSSION}

PIFP is a disease difficult to diagnosis since many of its symptoms are common to other orofacial syndromes. Thus, it is important to use the process of exclusion, i.e., differential diagnosis, in designing an effective therapeutic plan, avoiding the application of unnecessary, invasive procedures.

The patient was diagnosed with TN, although the clinical picture presented divergences that should have ruled out this diagnosis. This error is constantly seen among health professionals due to scarce literature production and the low incidence and prevalence of the disease.

As mentioned before, a differential diagnosis is challenging, but possible when a meticulous evaluation of symptoms is performed. Looking closely at other common pathologies one can 
see the differences between PIFP and them ${ }^{9}$. As with PIFP, TN is also a rare syndrome, but its pain starts abruptly, occurs in outbursts/paroxysms lasting from seconds to minutes, and is characterized as sharp and a shock with a burning sensation after the crisis. In PIFP, pain comes on slowly and gradually, it's continuous and diffuse and has the profile of being penetrating, painful and paralyzing. PIFP can still occur secondarily to an injury or pathology of the trigeminal system, making the diagnosis even more of a meticulous process. The two syndromes also differ in irradiation: TN normally follows the path of the nerve branches while PIFP is deep and poorly located and can radiate throughout the face, head and intraoral region ${ }^{2}$.

PIFP can also be confused with TMJD, a pathology defined by a set of clinical problems involving both masticatory musculature and the temporomandibular joint (TMJ). TMJD generates focused pain on the face, more precisely in the masseter region, mandible, around the TMJ and near the retromolar trigone area. Thus, the two pathologies can be differentiated by the extensiveness of the pain, in that PIFP is diffuse and undefined and TMJD occurs in a defined area. In turn, myofascial pain can be differentiated from PIFP by the presence of sensitive areas, called myofascial trigger points. These points are located in a tense muscular band and are able to produce a pattern of local or referred pain, generally asymmetrical, that may be bilateral ${ }^{9,10}$. According to Graff-Radford and Solberg and Vickers and Cousins, PIFP occurs in 3 to $6 \%$ of patients who undergo endodontic treatment. It is known that invasive procedures, including most dental treatments, can lead to the segmentation of nerve fibers. Regarding endodontic treatment, some authors affirm that deafferentation may be correlated with the origin of pain reported by the patient. This can occur due to an accidental or provoked injury to the nerve fibers, thus causing peripheral obstruction of an afferent pathway ${ }^{6,11,12}$.

In this way, the hypothesis that the presence of trauma in the periapical tissues (e.g., apicoectomy, removal of the pulp tissue, over instrumentation of the root canals), as well as small traumas caused by the blockage of the inferior alveolar or mental nerve, can lead to the deafferentation process ${ }^{13}$. In cases of over-instrumentation of root canals, the endodontic file will act beyond the limit of the apical foramen, reaching the periapical region, and may damage a nerve present in this region. Other possibilities that may explain the presence of constant pain as presented by the patient are extra root canals (high prevalence in lower premolars), the professional lacking sufficient anatomical knowledge or due to an anatomical difficulty present in the root canal system. Associated with all these mentioned factors, the patient may still present poor pain modulation, which would be a further stimulus for the continuation of painful symptoms without mediating neuropeptides, generating neuropathic pain ${ }^{14,15}$.

The diagnostic criteria for PIFP are: 1) Facial pain, daily and high persistence; 2) Deep and poorly localized pain restricted to an area limited to a hemiface; 3) Pain without sensory loss or other physical signs; 4) Face and jaw X-rays without relevant abnormalities ${ }^{16}$. Thus, after the exclusion of other pain syndromes described above (TMJD, TN and myofascial pain), analysis of the imaging tests and application of the diagnostic criteria for PIFP, the diagnosis was established. The pharmacological treatment was based on the use of anticonvulsants (pregabalin $450 \mathrm{mg}$ ), associated with serotonin and noradrenaline reuptake selective inhibitor antidepressant (venlafaxine $150 \mathrm{mg}$ ), a standard treatment for neuropathic pain, according to the IASP. Although PIFP is a painful condition of complex etiology, often undefined, it has a neuropathic origin ${ }^{7}$. Pregabalin was chosen because it has a better pharmacological profile when compared to Gabapentin. In addition, Pregabalin has been associated with lower pain levels compared to Gabapentin, despite its higher $\operatorname{cost}^{17}$. The association of anticonvulsants with tricyclic antidepressants or selective serotonin and noradrenaline reuptake inhibitors, although also used in the treatment of PIFD, had no clinical evidence ${ }^{7}$.

An alternative that emerged recently in an attempt to improve the quality of life of patients with PIFP is the application of botulinum toxin type A (BTX-A). BTX-A can perform as an analgesic by inhibiting the release of substance $P$ and calcitonin, thus reducing peripheral nociception. It has also been shown to be safe and efficient in the treatment of refractory TN ${ }^{16}$. Borodic and Acquadro ${ }^{18}$, in a pilot study, treated patients with chronic facial pain with botulinum toxin in the painful areas, and of the 11 treated patients with TN, 8 showed a reduction of at least $50 \%$ in the frequency and intensity of painful episodes, with results lasting between 2 and 4 months. The therapy used for the treatment of TN and PIFP are similar ${ }^{19}$, so it was decided to use botulinum toxin, but expected positive results weren't obtained. Another therapy used in the current case was acupuncture. The use of acupuncture is an important tool in the management of PIFP, and it was effective in the present case, in which there was seen a reduction in pain intensity and improvement of sleep pattern, as well as helping with anxiety. Acupuncture can alleviate both mechanical hyperalgesia and pain-induced anxiety in a neuropathic pain model in rats, a therapy that can act on both sensory and affective dimensions of pain. Its effect may arise from the regulation of phosphorylation of extracellular signal-regulated kinase (p-ERK) in anterior cingulate cortex (ACC) neurons ${ }^{20}$.

The prevention of PIFP is not commonly used because it is complex and of low incidence. But as patients who develop PIFP suffer from most psychic disorders, including anxiety, depression, obsessive-compulsive disorder, hysteria and post-traumatic syndrome, a possible way to prevent the development of the disease is the use of short-acting benzodiazepines before endodontic procedures or psychotherapy in those with a greater predisposition for developing PIFP $^{2}$.

In its chronic form, pain ceases to serve the biological function of giving an alert and, instead, often gives rise to changes in physiological (sleep disturbance, appetite), emotional (depression, anxiety), behavioral (physical disability, dependence on others) and social (family conflicts, occupational problems) areas. It is more difficult to diagnose and treat it when compared to acute pain $^{21}$. Its main long-term consequence is the establishment of a behavioral repertoire depleted and maintained by aversive stimuli (successive attempts to control and avoid pain) and the gradual reduction of significant life activities. Therefore, work related to the context of the symptom, before physical rehabilitation, has been shown to be effective. 
As illustrated in this report, patients with poor outcome during treatment may experience benefits from meditation, relaxation, and hypnosis ${ }^{2}$. In recent years the use of such practices has been expanding and contributing not only directly to pain management, but also to its psychosocial components. In addition, they represent low-cost instruments which provide effective results.

As PIFP is a disease that is difficult to diagnose and has a high impact on the lives of those affected, it is necessary to train all health professionals who work with orofacial pain. They need to be trained in order to be prepared to prevent its occurrence, mainly focusing on dental surgeons, as well as for the establishment of an accurate diagnosis and an effective treatment plan.

Along these same lines, PIFP should be managed by a multi/interdisciplinary team that seeks the establishment of a therapeutic plan that aims for a reduction in crises and pain symptoms, as well as the maintenance of patients' autonomy and quality of life. This means avoiding iatrogenic procedures, which, without positive results, end up generating discomfort and suffering in the patient, contributing to the delay in identification and poor prognosis in the evolution of PIFP.

\section{REFERENCES}

1. Siqueira JTT, Teixeira MJ. Dores Orofaciais: Diagnóstico e Tratamento. Curitiba: Artes Médicas; 2009. Cap. 35, 409-14p.

2. Teixeira MJ, Siqueira SR. Neuralgias do segmento facial. J Bras Ocl ATM Dor Orof. 2003;3(10):101-10

3. Ciampi de Andrade D, Lefaucheur JP, Galhardoni R, Ferreira KS, Brandão Paiva AR, Bor-Seng-Shu E, et al. Subthalamic deep brain stimulation modulates small fiber-dependent sensory thresholds in Parkinsons' disease. Pain. 2002;153(5):1107-13.
4. Nóbrega JC, Siqueira SR, Siqueira JT, Teixeira MJ. Diferential diagnosis in atypical facial pain: a clinical study. Arq Neuropsiquiatr. 2007;65(2A):256-61.

5. Woda A, Pionchon P. A unified of concept of idiophatic orofacial pain: clinical features. J Orofac Pain. 1999.13(3):172-85.

6. Graff-Radford SB, Solberg WK. Atypical odontalgia. J Craniomand Disord. 1992;6(4):260-5.

7. International Association for the Study of Pain. Persistent Idiopathic Facial Pain (Previously "Atypical Facial Pain”). IASP, Seattle. 2016.

8. Ramos, JL, Peres RS. Protocolo de avaliaçăo psicológica para pacientes oncológicos: uma proposta. Psicol Argum. 2013;31(75):729-37.

9. Gazi MC, Issy AM, Ávila IP, Sakata RK. Comparison of acupuncture to injection for myofascial trigger point pain. Pain Pract. 2011;11(2):132-8.

10. Shah JP, Heimur J. New frontiers in the pathophysiology of myofascial pain. Pain Practioner. 2012;22(2)26-34.

11. Ram S, Teruel A, Kumar S, Clark G. Clinical characteristics and diagnosis of atypical odontalgia: implications for dentists. J Am Dent Assoc. 2009;140(2):223-8.

12. Vickers ER, Cousins MJ (2000). Neuropathic orofacial in: part 1--prevalence and pathophysiology. Aust Endod J. 2000;26(1):19-26.

13. Lilly JP, Law AS. Atypical odontalgia misdiagnosed as odontogenic pain: a case report and discussion of treatment. J Endod. 1997;23(5):337-9.

14. Ram S, Teruel A, Kumar SK, Clark G. Clinical characteristics and diagnosis of atypical odontalgia: implications for dentists. J Am Dent Assoc. 2009;140(2):223-8.

15. Mellis M, Secci S. Diagnosis and treatment of atypical odontalgia: a review of the literature and two case reports. J Contemp Dent Pract. 2007;8(3):81-9.

16. Alves Neto O. Dor - Princípios e Prática. Săo Paulo: Artes Médicas; 2009; Cap. 58.

17. Wang BC, Liu D, Furnback WE, Bifa F, Dong P, Xie L, et al. The cost-effectiveness of pregabalin versus gabapentin for peripheral neuropathic pain $(\mathrm{pNeP})$ and postherpetic neuralgia (PHN) in China. Pain Ther. 2016;5(1):81-91.

18. Borodic GE, Acquadro MA. The use of botulinum toxin for the treatment of chronic facial pain. J Pain. 2002;3(1):21-7.

19. Wu CJ, Lian YJ, Zheng YK, Zhang HF, Chen Y, Xie NC, et al. Botulinum toxin type A for the treatment of trigeminal neuralgia: results from a randomized, double-blind, placebo-controlled trial. Cephalalgia. 2002;32(6):443-50.

20. Shao XM, Shen Z, Sun J, Fang F, Fang JF, Wu YY, et al (2015). Strong manual acupuncture stimulation of "Huantiao" (GB 30) reduces pain-induced anxiety and p-ERK in the anterior cingulate cortex in a rat model of neuropathic pain. Evid Based Complement Alternat Med. 2015;2015:235491.

21. Portnoi AG. Dor, Stress e Coping: Grupos Operativos em Doentes com Síndrome de Fibromialgia. Tese de Doutorado náo publicada. Universidade de São Paulo, São Paulo. 1999. 